\title{
Phosphorylated thiacalixarenes as molecular receptors for QCM sensors of volatile compounds
}

\author{
Z.I.Kazantseva ${ }^{1}$, I.A.Koshets ${ }^{1}$, A.E.Belyaev ${ }^{1}$, A.B.Ryabitskii ${ }^{2}$, \\ S.G.Kharchenko ${ }^{2}$, A.B.Drapailo ${ }^{2}, V_{\text {I.Kalchenko }}{ }^{2}$, \\ S.V.Shishkina ${ }^{3}$, O.V.Shishkin ${ }^{3}$ \\ ${ }^{1}$ Institute of Semiconductor Physics, National Academy of Sciences of \\ Ukraine, 41 Nauki Ave., 03028 Kyiv, Ukraine \\ ${ }^{2}$ Institute of Organic Chemistry, National Academy of Sciences of \\ Ukraine, 5 Murmanska Str., 02660 Kyiv, Ukraine \\ ${ }^{3}$ State Scientific Institution "Institute of Single Crystals", National \\ Academy of Sciences of Ukraine, 60 Nauki Ave., 61001 Kharkiv, Ukraine
}

Received June 1, 2017

\begin{abstract}
Sorption of volatile organic compounds and ammonia by thin solid films of phosphorylated thiacalixarenes was investigated by the quartz crystal microbalance (QCM), X-ray crystallography and molecular modeling methods The interfacial sorption depends on the number and position (upper or lower rim) of $P=O$ groups on the macrocyclic skeleton, the electronic nature of the substituents at the phosphorus atom. At low concentrations of the analytes their sorption occurs according to the Langmuir isotherm due to specific supramolecular interactions with receptor centers of the thiacalixarenes. The analytes may form either the Host-Guest inclusion complexes stabilized by $\mathrm{C}-\mathrm{H} \ldots \pi$ interactions, or extracavity complexes stabilized by hydrogen bonds with oxygen atoms of the peripheral $P=O$ groups. At high concentrations, when the thiacalixarene receptor centers are occupied by the analytes, further sorption occurs nonspecifically according to the linear Henry isotherm due to inclusion of the analytes in voids of the crystal structure of the thiacalixarenes.

Keywords: phosphorylated thiacalixarenes, QCM sensor, X-ray crystallography analysis, molecular modeling, volatile organic compounds.

\footnotetext{
Абсорбция летучих органических веществ и аммиака тонкими пленками фосфоризависит от количества и позиции (нижний или верхний обод) $\mathrm{P}=\mathrm{O}$ групп остова макронию аналита в полости кристаллической структуры тиакаликсаренов.
} лированных тиакаликсаренов исследованы методами кварцевого микробаланса (КМ), рентгеноструктурного анализа и молекулярного моделирования. Межфазная сорбция цикла и әлектронных состояний атомов фосфора в заместителях. При низких концентрациях сорбция аналита имеет вид ленгмюровской изотермы благодаря специфическим супрамолекулярным взаимодействиям с рецепторными центрами тиакаликсаренов. Аналиты могут формировать включения типа "гость - хозяин", которые стабилизированы C-H...л связями, или межмолекулярные комплексы, стабилизированные водородными связями с атомами кислорода периферийных $\mathrm{P}=\mathrm{O}$ групп. При высоких концентрациях, когда тиакаликсареновые рецепторные центры заняты аналитом, дальнейшая абсорбция происходит неспецифично по линейной изотерме Генри, благодаря включе-
\end{abstract}




\begin{abstract}
Фосфорильовані тіакаліксарени як молекулярні рецептори для сенсорів на основі КМ щодо летючих речовин. З.І.Казанцева, І.А.Кошець, О.Є.Бєляєв, О.В.Рябицький, С.Г.Харченко, А.<.Драпайло, В.І.Кальченко, С.В.Шишкіна, О.В.Шишкін.

Абсорбцію летючих органічних речовин та амоніаку тонкими плівками фосфорильованих тіакаліксаренів досліджено методами кварцового мікробалансу (КМ), рентгеноструктурного аналізу та молекулярного моделювання. Міжфазна сорбція залежить від кількості та позиції (нижній чи верхній вінець) $\mathrm{P}=\mathrm{O}$ груп в остові макроциклу та електронних станів атомів фосфору у замісниках. При низьких концентраціях сорбція аналіту має вигляд ленгмюрівської ізотерми завдяки специфічним супрамолекулярним взаємодіям із рецепторними центрами тіакаліксаренів. Аналіти можуть формувати включення типу "гість - хазяїн", що стабілізовані C-H...л зв'язками, або міжмолекулярні комплекси, стабілізовані водневими зв'язками з атомами кисню периферійних $\mathrm{P}=\mathrm{O}$ груп. При великих концентраціях, коли тіакаліксаренові рецепторні центри зайняті аналітом, подальша абсорбція відбувається неспецифічно за лінійною ізотермою Генрі завдяки включенню аналіту у порожнини кристалічної структури тіакаліксаренів.
\end{abstract}

\section{Introduction}

Chemosensors allow the timely identification of various (including hazardous) substances in solution and in the gas phase. A chemosensor consists of a sensing element which is capable of interacting with an analyte and a device (transducer) which converts the events of molecular recognition into a measurable optical, electrochemical or any other signal. Promising classes of sensing elements are based on two dimensional solid materials which have a large surface area and are capable of fast, selective and reversible binding to the analyte. The selectivity and strength of this binding is, to a large extent, determined by the nature of the non-covalent interactions between molecules on the surface and the analyte $[1,2]$. Therefore, a crucial aspect of chemical sensor development is synthesis of sensitive and selective materials that exhibit stable and reproducible adsorption of analyte molecules [3-7].

Previous studies showed that three dimensional macrocyclic molecules such as cavitands [8-10] or calixarenes [11-16] are promising compounds for fabrication of the layers. Dalcanale and Dutasta have demonstrated that phosphoryl groups grafted on the resorcinarene skeleton dramatically increases its sensing properties to neutral organic molecules, metal or ammonium cations [17-21]. In this case the oxygen atoms of $\mathrm{P}=\mathrm{O}$ groups participate in binding of the analytes by hydrogen bonds or ion-dipole supramolecular interactions.

QCM method was used to show that placement of phosphoryl groups at the calix[4]arene upper rim leads to specific sorption of alcohols through $\mathrm{P}=\mathrm{O}$... $\mathrm{H}-\mathrm{O}$ hydrogen bonding [22]. The QCM measurement technique uses the sensitivity of quartz crystal resonator with respect to any mass change at its surface in according to Sauerbrey relation [23]. Sensitivity of the QCM sensors is sufficiently high to discern very small fraction of adsorbates in solid films. Total mass changes of less than a nanogram can be observed using the QCM method. QCM sensors are widely used in many practical applications in gaseous and liquid medium.

Thiacalix[4]arenes [24] that are larger in size and contain four sulfur atom linkers in the macrocyclic skeleton were previously shown to be promising as a basis for various receptors [25-27]. This paper focuses on investigation of sensing properties of tetrahydroxythiacalix[4]arenes 1 . In particular, effects of the upper and lower rim phosphoryl derivatives 2-4 (Chart 1) to volatile molecules at sensitive film - gas interphase are investigated by the QCM, X-ray crystallography and molecular modeling methods.

\section{Methods and materials}

\subsection{Synthesis of the thiacalixarenes}

Thiacalixarenes 1 [28], 2 [29] were prepared according to the published procedures. Tribromotrihydroxythiacalixarene phosphine oxide 3a was synthesized with $87 \%$ yield by the regioselective bromination of trihydroxythiacalixarene phosphine oxide 2a with $\mathrm{N}$-bromosuccinimide in acetone solution (Scheme 1). Trinitrotrihydroxythiacalixarene phosphine oxide $3 \mathrm{~b}$ was obtained with $85 \%$ yield by the reaction of $2 \mathrm{a}$ with acetyl nitrate in 1:1 chloroform/acetic acid solution (Scheme 1).

Tetraphosphorylated tetrahydroxythiacalixarenes $4 \mathrm{a}-\mathrm{g}$ were synthesized with high yields by the Arbuzov reaction of chloromethylthiacalixarene 5 according method [30] (Scheme 2). 


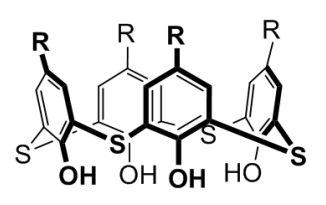

$1 a, b$

$\mathrm{R}=\mathrm{H}(\mathbf{a}), t-\mathrm{Bu}(\mathbf{b})$

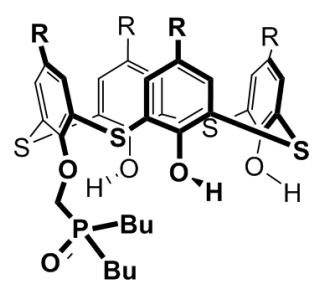

$2 a, b$

$\mathrm{R}=\mathrm{H}(\mathrm{a}), t-\mathrm{Bu}(\mathbf{b})$

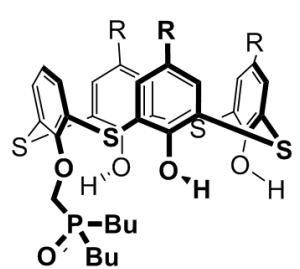

3a,b

$\mathrm{R}=\mathrm{Br}(\mathbf{a}), \mathrm{NO}_{2}$ (b)

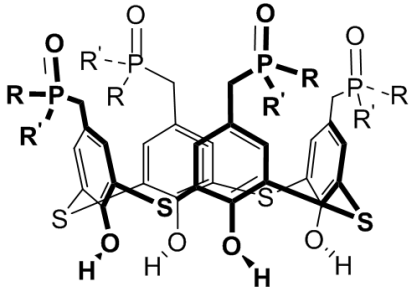

4a-g

$R=O P r-i, R^{\prime}=E t(a)$

$\mathrm{R}=\mathrm{R}^{\prime}=\operatorname{Pr}-\mathrm{i}(\mathbf{b})$

$\mathrm{R}=\mathrm{R}^{\prime}=\mathrm{Et}(\mathbf{c})$
$\mathrm{R}=$ Oct, $\mathrm{R}^{\prime}=\mathrm{Ph}(\mathbf{d})$

$\mathrm{R}=\mathrm{R}^{\prime}=\mathrm{Bu}(\mathrm{e})$

$\mathrm{R}=\mathrm{R}^{\prime}=\mathrm{Ph}(\mathbf{f})$

$\mathrm{R}=\mathrm{R}^{\prime}=$ OEt $(\mathbf{g})$

Chart 1. Chemical structures of thiacalix[4]arenes 1-4.

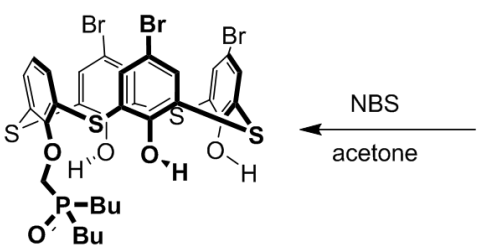

$3 a$

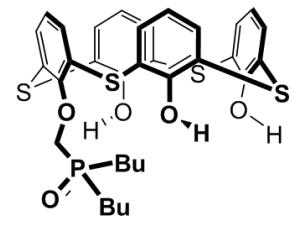

$2 a$

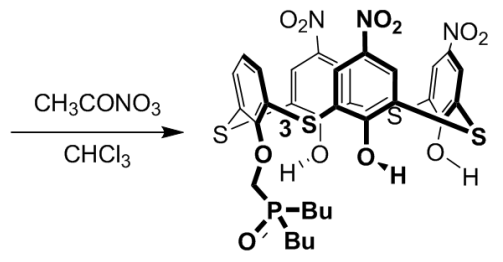

$3 b$

Scheme 1. Synthesis of tribromo- and trinitrothiacalixarene phosphine oxides 3a,b.

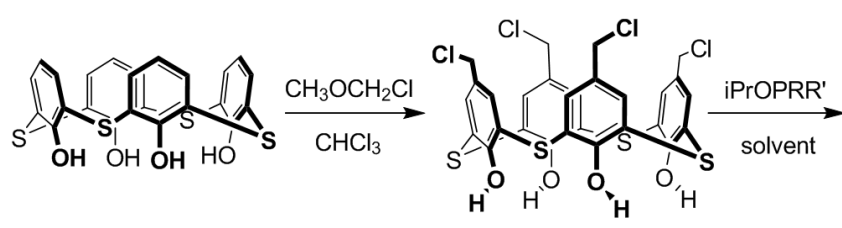

$1 \mathrm{a}$

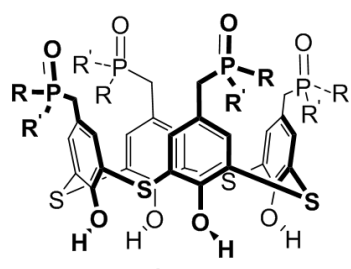

4a-g

Scheme 2. Synthesis of the upper rim tetraphosphorylated thiacalixarenes $4 \mathrm{a}-\mathrm{g}$.

All experimental details, physicochemical properties and NMR spectra of new compounds $3 a-b$ and $4 a-d$ are described in the Supporting information.

\section{2. $X$-ray analysis}

$\mathrm{X}$-ray molecular structure of thiacalixarene phosphine oxide $2 \mathrm{~b}$ was described in [29]. X-Ray molecular and crystal structures of tetrabromothiacalixarene phosphine oxide $3 \mathrm{a}$ were determined as follow. The colorless crystals of $\mathrm{C}_{33} \mathrm{H}_{32} \mathrm{O}_{5} \mathrm{PS}_{4} \mathrm{Br}_{3}$ are monoclinic. At $100 \mathrm{~K} a=12.6013(3), b=$ 15.8302(4), $c=18.1588(4) \AA, \beta=91.341(2)^{\circ}$, $V=3621.4(2) \AA^{3}, \quad M r=907.53, \quad Z=4$, space group $P 2_{1} / n, d_{\text {calc }}=1.665 \mathrm{~g} / \mathrm{cm}^{3}$, $\mu\left(\right.$ MoK $\left._{\alpha}\right)=3.656 \mathrm{~mm}^{-1}, \quad F(000)=1816$. Intensities of 38594 reflections (10556 independent, $R_{\text {int }}=0.026$ ) were measured on the "Xcalibur-3" diffractometer (graphite monochromated $\mathrm{MoK}_{\alpha}$ radiation, CCD detec- tor, $\omega$-scaning, $2 \theta_{\max }=60^{\circ}$ ). The structure was solved by direct method using SHELXTL package [Sheldrick GM (2008) Acta Crystallogr Sect A A64:112-122]. The absorption correction was performed using the multi-scan method $\left(T_{\min }=0.407, T_{\max }\right.$ $=0.711)$. Positions of the hydrogen atoms were located from electron density difference maps and refined by "riding" model with $U_{i s o}=n U_{e q}$ of the carrier atom $(n=$ 1.5 for methyl groups and $n=1.2$ for other hydrogen atoms). The hydrogen atoms of hydroxyl groups are refined using isotropic approximation. Full-matrix least-squares refinement against $F^{2}$ in anisotropic approximation for non-hydrogen atoms (429 parameters) using 10496 reflections was converged to $\mathrm{wR} 2=0.065 \quad(\mathrm{R} 1=0.028$ for 9143 reflections with $F>4 \sigma(F), S=1.032)$. The final atomic coordinates, and crystallographic data for molecule $3 a$ have been 
deposited to with the Cambridge Crystallographic Data Centre, 12 Union Road, CB2 1EZ, UK (fax: +44-1223-336033; e-mail: deposit@ccdc.cam.ac.uk) and are available on request quoting the deposition numbers CCDC 1415552.

\subsection{Molecular modeling}

Molecular modeling was performed using computational facilities of the SSI "Institute of Single Crystals" NAS of Ukraine incorporated into Ukrainian National Grid.

\subsection{QCM experimental setup}

QCM-based chemosensory device [31] designed and fabricated in the Institute of Semiconductor Physics, NAS of Ukraine was used in our experiments on sensing properties of thiacalixarenes. The device consists of 8-channel QCM-based sensor array, a working cell, gas-supplying pathways, a vapor injection system, an air filter-drier providing fresh dry air for purging sensors between sampling, a valve for switching between sampling and purging and electronics (quartz oscillators, frequency counters, and interfacing with $\mathrm{PC}$ ). Experiment controlling and data acquisition are carried out by means of original software. Standard radiofrequency quartz resonators $(10 \mathrm{MHz}$, AT-cut, $\varnothing 8 \mathrm{~mm})$ covered with appropriable thiacalixarene sensitive layers are used as the sensor elements.

For immobilization of the thiacalixarene sensing layers well-proven the centrifugation (spin-coating) and the spreading drop methods were used. Thiacalixarenes were dissolved in chloroform at a concentration of $1 \mathrm{mg}$ per $\mathrm{mL}$. The sensitive coating thickness was adjusted by amount of solution dropped onto sensor's surface Testing of the thiacixarene sensitive layers was carried out using a single-channel QCM sensor system. The effective mass thickness of the film corresponded to frequency shifts of sensors was within $4000-4500 \mathrm{~Hz}$ range and $2500 \ldots 8500 \mathrm{~Hz}$ for film thickness study.

\section{Results and discussions}

The eight different thiacalixarene based sensors were collected into sensors array that was inserted in the chemosensory device described above. The specified concentration of the analyte was provided by gas mixtures generator based on the diffusion tube principle [32]. Acetone, acetonitrile, butylacetate, hexane, toluene, chloroform and ammonia were tested as analytes. All QCM measurements were carried out under
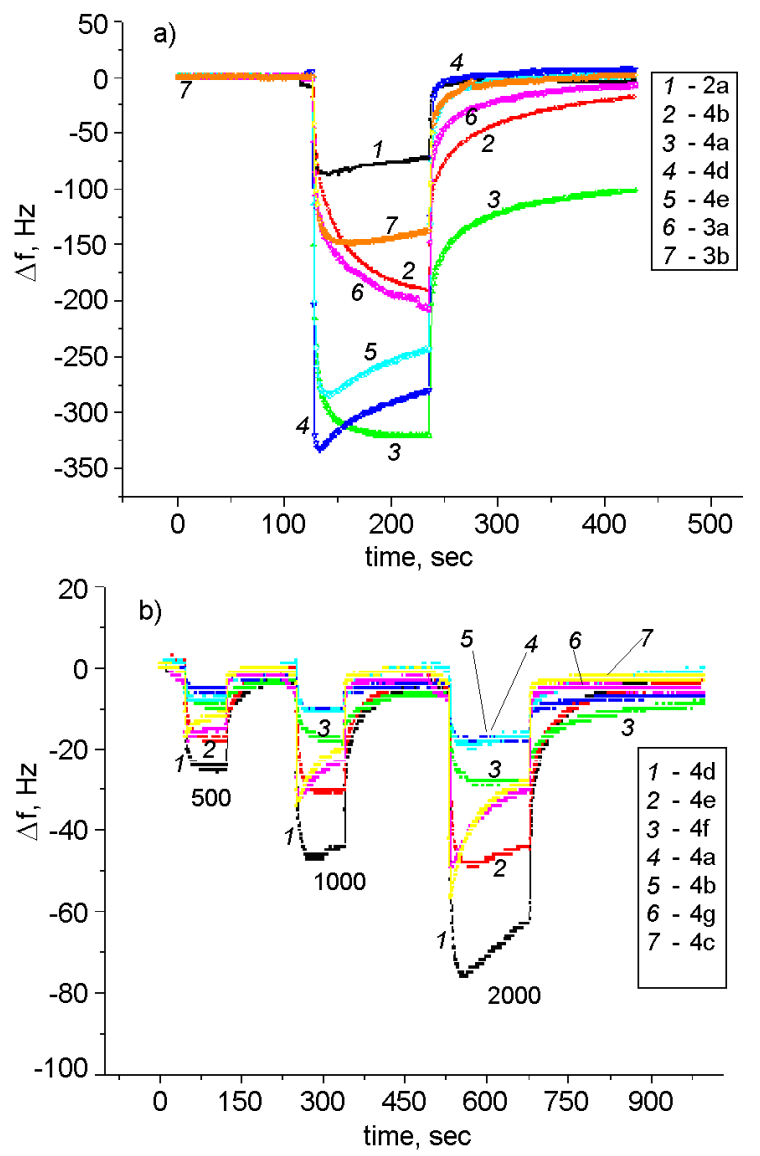

Fig. 1. Responses of sensors $2 \mathrm{a}, 3 \mathrm{a}, 3 \mathrm{~b}, 4 \mathrm{a}$, $4 \mathrm{~b}, 4 \mathrm{~d}, 4 \mathrm{e}$ on injection of high $(1 / 2$ of saturated vapor pressure) concentration of acetone (a) and $4 \mathrm{a}-\mathrm{f}$ on injection of consequently increasing concentration $(500,1000$ and $2000 \mathrm{ppm}$ ) of toluene (b).

normal conditions (193.15 $\mathrm{K}$ and $760 \mathrm{mmHg}$ ).

Typical kinetic responses of sensors on injection of high (approx. one half of saturated vapor pressure) and subsequently increasing concentration $(500 \ldots 2000 \mathrm{ppm})$ of analyte in the working cell are presented in Fig. 1a, b respectively. One can see significantly different shape of curves: fast response with maximum and a successive dip in the curve as well as a slowly increasing response reaching some stable magnitude.

Such a behavior can be attributed to two reasons. The first is a no-flow mode of sensory system; the second is that different functional groups of tiacalixarenes possess different affinity features towards various analytes. Thiacalixarene $4 \mathrm{a}$ and $4 \mathrm{~b}$ demonstrate sensitivity to acetone, acetonitrile, ammonia and ethanol. Because compound $4 \mathrm{a}$ has a more proton-accepting $\mathrm{P}=\mathrm{O}$ group compared with $4 \mathrm{~b} \mathrm{P}=\mathrm{O}$ group, the incom- 

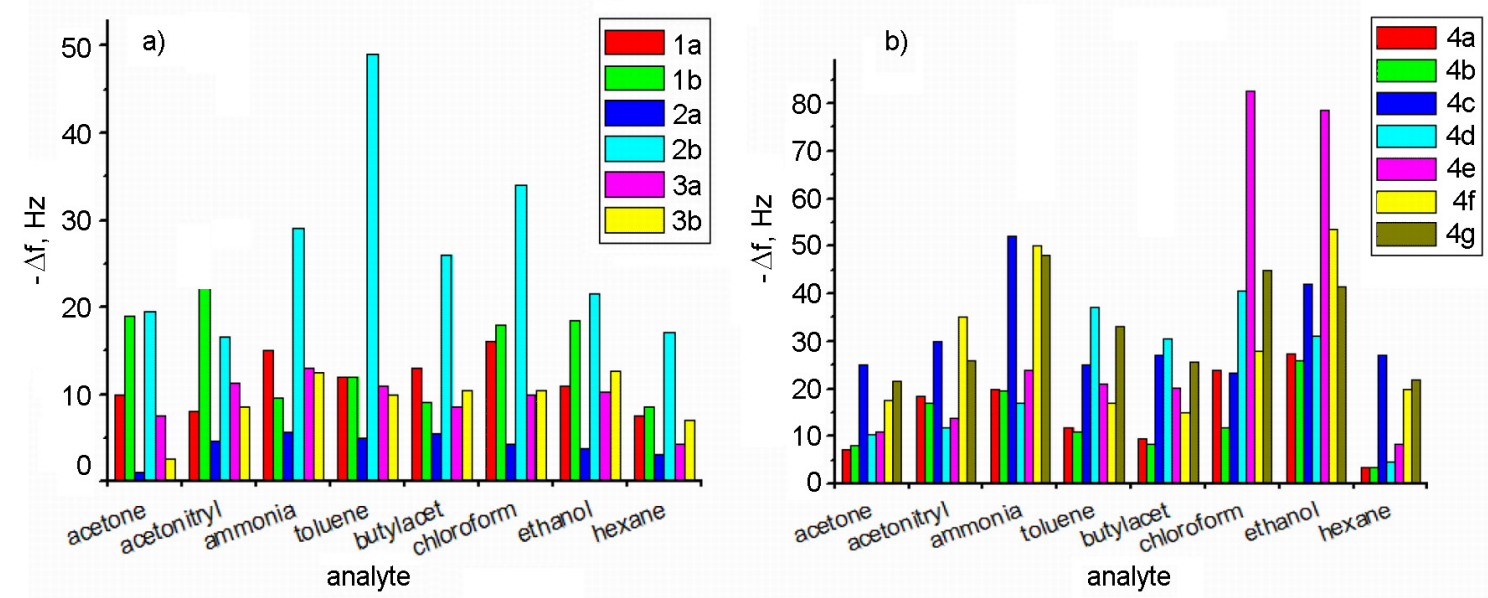

Fig. 2. Responses of the QCM sensors coated with thiacalixarenes $1,2,3$ (a) and 4 (b) on injection of various analytes (1000 ppm).
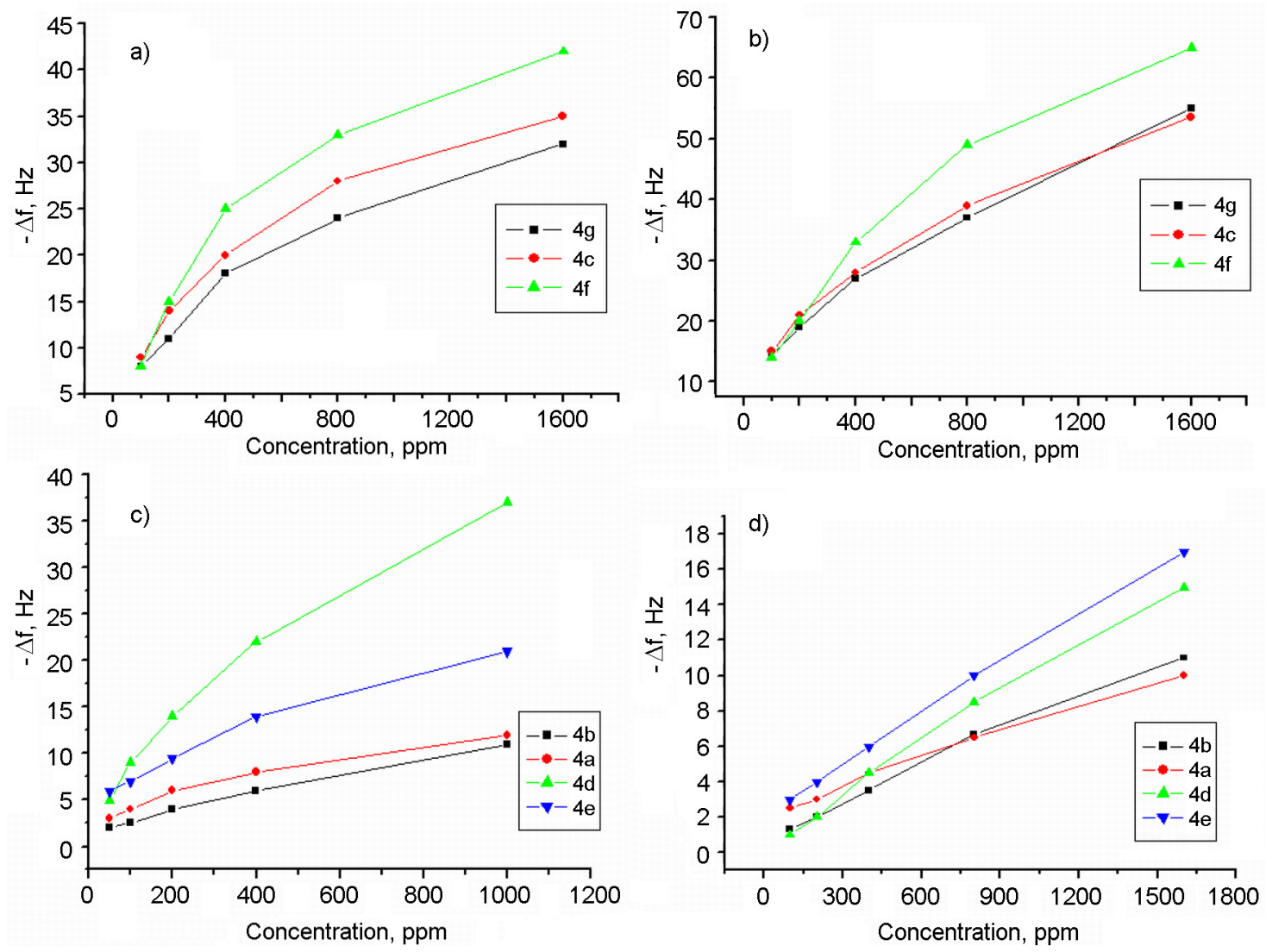

Fig. 3. Concentration dependencies of sensors covered with thiacalixarenes 4 towards acetonitrile (a), ethanol (b), toluene (c), acetone (d).

plete sensor recovery during purging of the sensor cell with fresh air is likely to occur (Fig. 1a). To obtain a full recovery it is necessary to heat the sensor up to $35-40^{\circ} \mathrm{C}$. Upon heating sensor recovery occurs within a couple of minutes even after exposure to very high analyte concentrations (Fig. 1b).
Responses of thiacalixarenes 1-4 sensor arrays on injection of the analytes at a concentration of $1000 \mathrm{ppm}$ are presented in Fig. 2. As can be seen in Fig. 2a functionalization of thiacalixarene lower rim with phosphine oxide group (compounds 2, 3) gives little effect on the sensors sensitivity. The exception is a response of tert- 


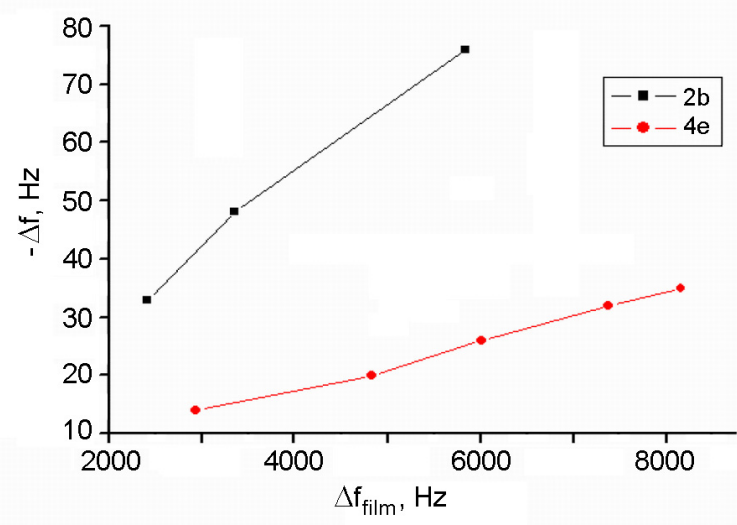

Fig. 4. Dependencies of the sensors (covered with $2 \mathrm{~b}$ and $4 \mathrm{e}$ thiacalixarenes) responses on toluene (1000 ppm) injections vs. "effective" film thickness $\Delta f_{\text {film }}$ (frequency shift due to mass of the sensitive film immobilized).

butylthiacalixarene phosphine oxide $2 \mathrm{~b}$ on toluene. Its sensitivity $(\Delta f=50 \mathrm{~Hz})$ is 2.5 times higher than sensitivity of tertbutylthiacalixarene $1 \mathrm{~b}$ and 5 times higher than sensitivity of tert-butyl depleted thiacalixarene $1 \mathrm{a}$.

Introduction of the four $\mathrm{P}=\mathrm{O}$ groups at the upper rim in most cases increases the sensors sensitivity (Fig. 2b). This is particularly evident for the binding of proton-donating analytes ethanol $(\Delta f=79 \mathrm{~Hz})$, ammonia $(\Delta f=52 \mathrm{~Hz})$, chloroform $(\Delta f=$ $82 \mathrm{~Hz}$ ), capable of forming hydrogen bonds with protonoaccepting $\mathrm{P}=\mathrm{O}$ groups of compounds $4 \mathrm{c}$, e, f. These compounds also exhibit selectivity in binding of the analytes. Tetraphosphine tetraoxide $4 \mathrm{e}$ shows the selectivity ratios for chloroform-hexane, ethanol-hexane, ethanol-acetone of 10:1, 10:1, and $7: 1$, respectively. The selectivity can be explained by the specific Host-Guest supramolecular interactions between thiacalixarenes and the analyte molecules.

The frequency shifts $(\Delta f)$ of the sensors coated with sensitive thiacalixarene layers are depended on the concentration of analytes (Fig. 3). For example, at relatively low concentrations of acetonitrile, ethanol or toluene their adsorption by phosphorylated thiacalixarenes 4 has a non-linear Langmuir shape (Fig. 3a-c) characteristic of specific Host-Guest binding. At high concentrations, when the thiacalixarene receptor centers are occupied by the analyte, the adsorption has linear Henry shape characteristic of nonspecific interactions. Linear Henry shape in the whole range of investigated concentrations is observed for sorption of acetone by 4 .

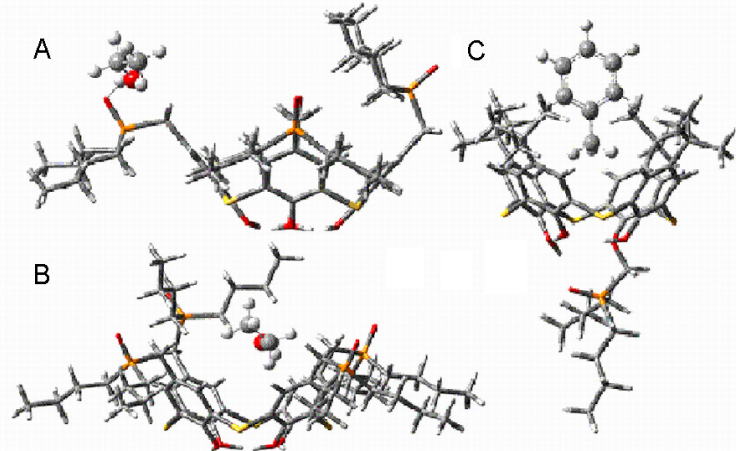

Fig. 5. The energy minimized structures: $\mathrm{OH} . . \mathrm{O}=\mathrm{P}$ hydrogen bonded extracavity complex of $4 \mathrm{e}$ with ethanol (A), intracavity inclusion complex of $4 \mathrm{e}$ with ethanol (B) and intracavity inclusion complex of $2 \mathrm{~b}$ with toluene (C).

Response of QCM sensor on toluene (and other analytes under study) sorption shows good linearity in respect to the mass of thiacalixarene sensitive layer (film) immobilized on the transducer surface (Fig. 4). It signifies that adsorption occurs in the bulk of such materials. In comparison with the layer formed by thiacalixarene tetraphosphine oxide $4 \mathrm{e}$, the tert-butylthiacalixarene phosphine oxide $2 \mathrm{~b}$ layer is more sensitive to the toluene sorption.

Thiacalixarenes layers can absorb analytes through specific supramolecular hostguest interaction with the macrocycles or through inclusion the analytes into porous crystal lattice. The mode and relative energies $G$ of the Host-Guest complexation of $4 \mathrm{e}$ with ethanol and $2 \mathrm{~b}$ with toluene were studied by molecular modeling methods B3LYP/6-31G(d) [33-35] using GAUSSIAN09 [36] program.

The energy minimized structures of the $\mathrm{OH} . . \mathrm{O}=\mathrm{P}$ hydrogen bonded extracavity complex $4 \mathrm{e}$ with ethanol (A), the intracavity inclusion complex $4 \mathrm{e}$ with ethanol (B) and the intracavity inclusion complex $2 \mathrm{~b}$ with toluene (C) are presented on Fig. 5. The ethanol hydrogen bonded complex (A) $(G=-11.6 \mathrm{kcal} / \mathrm{mol})$ is preferable compared to the inclusion complexes (B) $(G=-4.4 \mathrm{kcal} / \mathrm{mol})$ and $(\mathrm{C}) \quad(G=$ $-4.3 \mathrm{kcal} / \mathrm{mol})$.

The $2 \mathrm{~b}$-toluene complex $\mathrm{C}$ is stabilized by the specific $\mathrm{C}-\mathrm{H} . . . \pi$ interaction of the methyl groups with $\pi$-basic benzene rings of the macrocycle and $\mathrm{C}-\mathrm{H}$... interaction of the $t$-Bu groups of the macrocycle with benzene ring of toluene.

Nonspecific sorption of the analytes may occur through their inclusion in the voids 


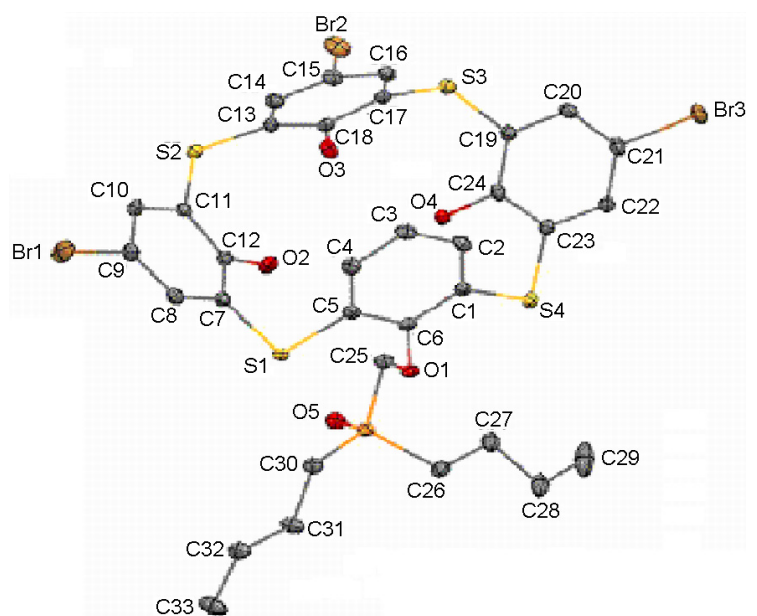

Fig. 6. X-Ray molecular structure of tribromothiacalixarene phosphine oxide 3a. Thermal ellipsoids are shown at the $50 \%$ probability level.

of the thiacalixarene crystal lattices (see Supporting Information). Tribromothiacalixarene phosphine oxide 3a existing in the cone conformation (Fig. 6) forms porous $3 \mathrm{D}$ crystal lattice due to the intermolecular $\mathrm{O}-\mathrm{H} . . \mathrm{O}=\mathrm{P}, \mathrm{O}-\mathrm{H} . . . \mathrm{O}^{\prime}, \mathrm{C}-\mathrm{H} . . . \mathrm{O}^{\prime}, \mathrm{C}-\mathrm{H} . . . \mathrm{S}^{\prime}$, $\mathrm{C}-\mathrm{H} . . . \pi$, hydrogen bonds and stacking interactions between the molecules. The voids located mainly in the thiacalixarene molecular cavities have volume $114.7 \AA^{3}$ of each and occupy $3.2 \%$ of the unit cell (Fig. 7).

The replacement of bromine atoms by tert-butyl groups at the upper rim results in the appreciable changing of the intermolecular interaction types in the cone shaped tert-butylthiacalixarene phosphine oxide $2 \mathrm{~b}$ (Fig. 8a) [29]. Only O-H.... $\mathrm{O}^{\prime}$ and $\mathrm{C}-\mathrm{H} \ldots \pi$ bonding is observed in the crystal $2 \mathrm{~b}$. Molecules $2 \mathrm{~b}$ form the $\mathrm{O}-\mathrm{H} \ldots \mathrm{O}=\mathrm{P}$ hydrogen bonded centrosymmetric dimer shown on Fig. 8b. Subsequently, the dimers form the columns along the $\left[\begin{array}{lll}1 & 0 & 0\end{array}\right]$ crystallographic direction due to formation a lot of $\mathrm{C}-\mathrm{H}$... $\pi$ interactions. The transparent voids (Fig. 9) between these columns have big enough size $\left(658.0 \AA^{3}\right)$ and volume fraction $(22.5 \%$ of unit cell) for effective sorption of the analytes.

\section{Conclusions}

The addition of $\mathrm{P}=\mathrm{O}$ groups on the thiacalix[4]arene macrocycle platform increases the efficiency and selectivity sorption of volatile compounds vapors from air at the solid-gas interface. The sorption depends on the number and position (upper or lower rim) of $\mathrm{P}=\mathrm{O}$ groups on the macrocyclic skeleton. At relatively low analyte concen-

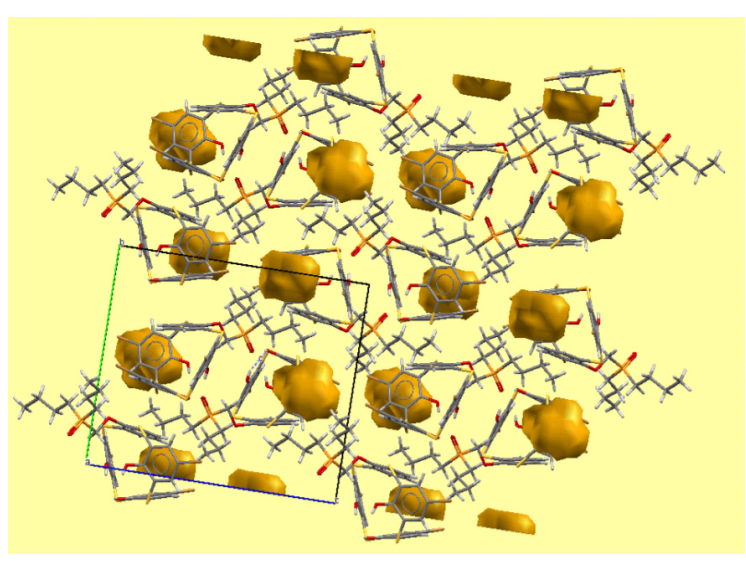

Fig. 7. Voids in the crystal lattice of tribromothiacalixarene phosphine oxide $3 a$ according to X-ray diffraction data.
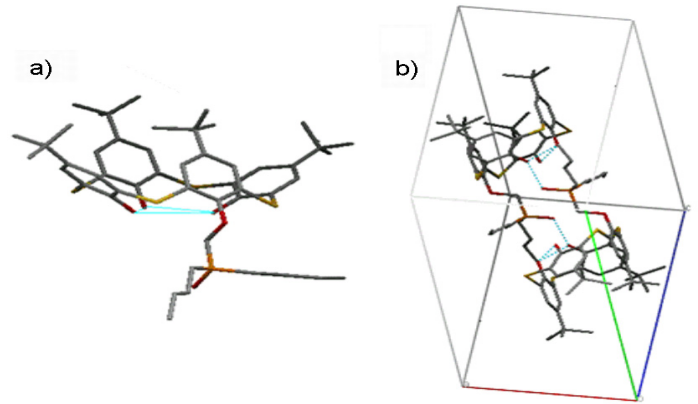

Fig. 8. Molecular structure of tert-butylthiacalixarene phosphine oxide $2 \mathrm{~b}$ (a) and its $\mathrm{O}-\mathrm{H} . . \mathrm{O}=\mathrm{P}$ hydrogen bonded dimer (b) according to X-ray diffraction data. Thermal ellipsoids are shown at the $50 \%$ probability level.

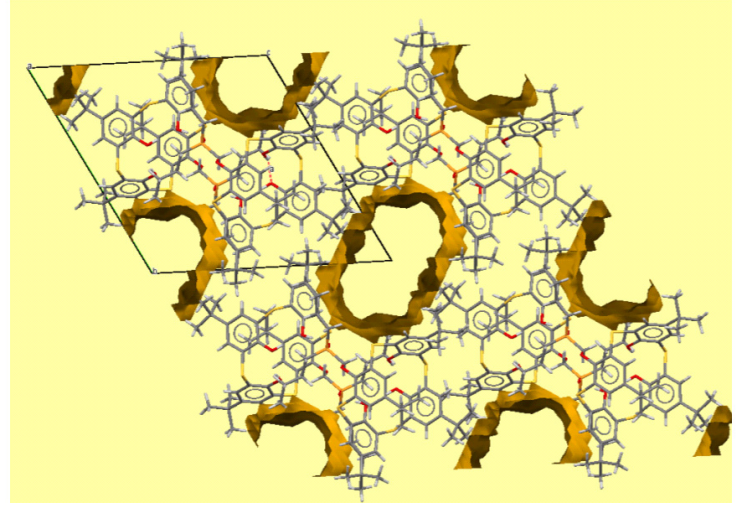

Fig. 9. Voids in the crystal lattice of tertbutylthiacalixarene phosphine oxide $3 \mathrm{a}$ in according to X-ray diffraction data.

trations the sorption takes place according to the Langmuir isotherm due to specific supramolecular interactions of the analytes with receptor centers of the thiacalixarenes. At higher concentrations, when the receptor centers are filled by the analyte molecules, further sorption is nonspecific as indicated by the Henry-type linear isotherm. Toluene 
molecule may form the intracavity inclusion host-guest complexes stabilized by $\mathrm{C}-\mathrm{H}$... interactions. Extracavity complexes of proton-donating ethanol molecule can be formed through hydrogen bonds with the basic oxygen atoms of the peripheral $P=0$ group. Nonspecific binding occurs due to the inclusion of the analytes in the voids of crystal lattice of thiacalixarenes. Thus phosphorylated thiacalixarenes are promising compounds for the formation of thin solid receptor layers on he QCM surfaces as a basis of chemical sensors.

Acknowledgements. This work was supported by the National Academy of Sciences of Ukraine within the program "Sensor devices for medical, environmental and industrial application".

Supplementary material. Supplementary material associated with this article can be found in the online version.

\section{References}

1. G.Orellana, M.C.Moreno-Bondi, Frontiers in Chemical Sensors: Novel Principles and Techniques, Springer, New York (2005).

2. B.Wang, E.V.Anslyn, Chemosensors: Principles, Strategies, and Applications, John Wiley \& Sons, Inc., Hoboken, New Jersey (2011).

3. W.Goepel, Sen.Actuators B-Chem., 18, 1 (1994).

4. K.Haupt, K.Mosbach, Chem.Rev., 100, 2495 (2000).

5. G.W.Gokel, W.M.Leevy, M.E.Weber, Chem. Rev., 104, 2723 (2004).

6. E.V.Anslyn, J.Org. Chem., 72, 687 (2007).

7. J.-P.Desvergne, A.W.Czarnik, Chemosensors of Ion and Molecule Recognition, ed. by J.-P.Desvergne, A.W.Czarnik, NATO ASI Series, Kluwer Academic, Dordrecht, The Netherlands (1997).

8. P.Nelli, E.Dalcanale, G.Faglia et al., Sen.Actuators $B, 13,302$ (1993).

9. F.Bianchi, A.Bedini, N.Riboni et al., Analyt. Chem., 86, 10646 (2014).

10. E.Biavardi, S.Federici, C.Tudisco et al., Angew. Chem. Int., 53, 9183 (2014).

11. F.L.Dickert, O.Schuster, Mikrochim. Acta, 119, 55 (1995).

12. D.Diamond, K.Nolan, Analyt. Chem., 73, 232001.

13. Y.Shirshov, B.Snopok, O.Rengevich et al., Relaxation of Nanostructured Molecular Materi- als under the Influence of Solvent Vapor, in book: Frontiers of Multifunctional Nanosystems, ed. by E.Buzaneva, P.Scarf, Kluwer Academic Publishers, The Netherlands (2002).

14. R.Zadmard, T.Schrader, J.Am.Chem.Soc., 127, 904 (2005).

15. I.A.Koshets, Z.I.Kazantseva, A.E.Belyaev, V.I.Kalchenko, Sen.Actuators B, 140, 104 (2009).

16. J.Vicens, J.Harrowfield, Calixarenes in the Nanoworld, ed. by J.Vicens, J.Harrowfield, Springer, Dordrecht, The Netherlands (2007).

17. R.Pinalli, E.Dalcanale, Acc.Chem.Res., 46, 399 (2013).

18. C.Tudisco, F.Bertani, M.T.Cambria et al., Nanoscale, 5, 11438 (2013).

19. M.Melegari, C.Massera, R.Pinalli, R.M. et al., Sen.Actuators B, 179, 74 (2013).

20. J.-P.Dutasta, Top.Curr.Chem., 232, 55 (2004).

21. P.Delangle, J.C.Mulatier, B.Tinant et al., Eur. J. Org. Chem., 19, 3695 (2001).

22. A.V.Solovyov, S.O.Cherenok, O.I.Kalchenko et al., J. Mol. Liquids, 159, 117 (2011).

23. G.Sauerbrey, Z.Phys., 155, 206 (1959).

24. N.Morohashi, F.Narumi, N.Iki et al., Chem. Rev., 106, 5291 (2006).

25. M.W.Hosseini, Thiacalixarenes a New Class of Receptor Molecules: Synthesis and Structural Analysis, in book: Calixarene Molecules for Separation, ed. by G.J.Lumetta, R.D.Rogers, A.S.Gopalan, ACS Series, 296 (2000).

26. T.H.Kim, H.Kim, J.H.Lee, J.S.Kim, Bull.Korean Chem.Soc., 29, 620 (2008).

27. V.K.Gupta, B.Sethi, R.A.Sharma et al., J. Mol. Liquids, 177, 114 (2013).

28. Y.Kumagai, M.Hasegawa, S.Miyanari et al., Tetrahedron Lett., 38, 3971 (1997).

29. S.Kharchenko, A.Drapailo, S.Shishkina et al., Supramolecular Chem., 26, 864 (2014).

30. O.Kasyan, D.Swierczynski, A.Drapailo et al., Tetrahedron Lett. 44, 7167 (2003).

31. V.I.Kalchenko, I.A.Koshets, E.P.Matsas et al., Mater. Sci., 20, 73 (2002).

32. J.M.McKelvey, H.E.Hoelscher, Analyt. Chem., 29, 123 (1957).

33. A.D.Becke, J.Chem.Phys., 98, 5648 (1993).

34. P.J.Stephens, F.J.Devlin, C.F.Chabalowski, M.J.Frisch, J.Phys.Chem., 98, 11623 (1994).

35. K.Kim, K.D.Jordan, J.Phys. Chem., 98, 10089 (1994).

36. Gaussian 09, Revision B.01, M.J.Frisch, G.W.Trucks, H.B.Schlegel et al., Gaussian Inc., Wallingford CT (2010). 